\title{
THE CONDITIONS OF USING OF LOYALTY PROGRAMS ON THE POLISH MARKET
}

\author{
(C)Howaniec Honorata B., 2017
}

Brand loyalty is a strategic asset of the company. Having loyal or faithful customers, in the era of competition, provides to business of essential benefits. Shaping of customer loyalty is not so easy. Companies, among others, by developing such elements as customer service quality and marketing communication quality, try to influence on customers' market behavior.

One of the tools of influence on customers' behavior is loyalty programs. Thanks to these, brand owners try to attract and retain customers by planning the reward system and trying to reward the most loyal customers by - on the one hand - providing them an additional value, and on the other hand - turning them into brand advocates, the most valuable customer group.

Popularity of loyalty programs in Poland is not very high. It is estimated that $25-40 \%$ of customers use loyalty programs. It is less than, for example, in the US or Canada. The benefits offered by most loyalty programs in Poland, however, are not high, and consumers think that the rewards they can get are very expensive and overpriced. Such a low assessment of the benefits of loyalty programs among customers negatively impact on their social acceptance. The change of business activities can change attitudes among Polish society. A positive example is the «My Ladybird» (in original «Moja Biedronka»), it is program introduced by the Biedronka discount chain, where both are the proposed bonuses and additional promotional campaigns, which were essentially targeted at children, proved to be a great success and have allowed them to outperform competitors with a recognized position in this area in just half a year. The attractiveness of the program has led to the active use it by 5 million households, which constitutes about $40 \%$ of all households in Poland.

The aim of the research is to present the concept of loyalty and the role of loyalty programs in shaping it. The author focused mainly on the conditions of today's popularity (or lack of it) available loyalty programs in Poland. Because of the availability of numerous studies of loyalty programs in Poland, secondary data was used in the study.

Key words: loyalty programs, brand loyalty, price promotion, retail.

Honorata B. Howaniec

Akademia Techniczno-Humanistyczna w Bielsku-Białej

\section{UWARUNKOWANIA KORZYSTANIA Z PROGRAMÓW LOJALNOŚCIOWYCH NA RYNKU POLSKIM}

(c) Howaniec Honorata B., 2017

Lojalność wobec marki jest strategicznym aktywem przedsiębiorstwa. W dobie konkurencji posiadanie lojalnych, czy - więcej - wiernych klientów dostarcza przedsiębiorstwa zasadniczych korzyści. Ksztaltowanie lojalności nabywców nie jest jednak latwe. Przedsiębiorstwa m.in. poprzez ksztaltowanie takich elementów, jak jakość obsługi klienta czy jakość komunikacji marketingowej starają się wpłynąć na postępowanie rynkowe klientów.

Jednym z narzędzi wpływu na zachowanie klientów są programy lojalnościowe. To przy ich pomocy wlaściciele marek starają się przyciągnąć i utrzymać klientów, planując odpowiednio system nagród starają się wynagradzać najwierniejszych klientów, dostarczając im $\mathrm{z}$ jednej strony dodatkowych wartości, a $\mathrm{z}$ drugiej zamieniając ich w adwokatów marki, czyli najbardziej wartościową grupę klientów. 
Popularność programów lojalnościowych w Polsce nie jest zbyt wysoka. Szacuje się, że klienci korzystający z programów lojalnościowych to $25-40 \%$. To mniej niż przykładowo w USA czy Kanadzie [5]. Korzyści oferowane przez większość programów lojalnościowych w Polsce nie są jednak wysokie, a konsumenci uważają, że nagrody, jakie można w nich uzyskać są bardzo drogie, a ich cena zawyżona. Tak niska ocena korzyści, jakich dostarczają programy lojalnościowe klientom negatywnie wpływa na ich odbiór społeczny. Zmiana postawy przedsiębiorstw może jednak skutecznie zachęcić do zmiany postaw wśród polskiego społeczeństwa. Pozytywnym przykładem jest program „Moja Biedronka” wprowadzony przez sieć dyskontów Biedronka, w którym zarówno proponowane bonusy, jak i dodatkowe akcje, których w zasadzie docelowym odbiorcą były dzieci, okazały się dużym sukcesem i pozwolił na wyprzedzenie konkurentów o uznanej w tym obszarze pozycji w ciągu zaledwie pól roku. Atrakcyjność programu spowodowała, że aktywnie korzysta $z$ niego $5 \mathrm{mln}$ gospodarstw domowych, co stanowi ok. 40\% wszystkich gospodarstw domowych w Polsce.

Celem opracowania jest przedstawienie pojęcia lojalności oraz roli programów lojalnościowych w jej kształtowaniu. Autorka skupiła uwagę głównie na uwarunkowaniach dzisiejszej popularności (czy jej braku) dostępnych programów lojalnościowych w Polsce. Ze względu na dostępność licznych badań programów lojalnościowych w Polsce, w opracowaniu wykorzystano dane wtórne.

Słowa kluczowe: programy lojalnościowe, lojalność wobec marki, promocja cenowa, handel detaliczny.

\section{Statement of the problem}

The concept of brand loyalty has many definitions. For example: G. R. Foxall i R. E. Goldsmith defines brand loyalty as an attachment to the species, it's meant the phenomenon of buying the same brand every time when the customer purchasing the product [6]. These authors do not explain the reasons for this attachment, thus presenting a broad definition of loyalty including the loyalty in the monopoly situation with the usually low degree of attachment to the brand [7]. J. O'Shaugnessy defining the concept of brand loyalty emphasizes the reason for attachment. According to his definition, loyalty to the brand is based on a personal and faithful attachment to «good and bad» to the brand [19]. Under this approach, an inherent attribute of loyalty is, therefore, persistence and personal motive for a positive attitude towards the brand. Slightly different definition of loyalty is given by G. Urbanek. According to him the brand loyalty is defined as not accidental, long-term behavior of the decision-making entity in relation to one or more brands, which is a function of psychological decision-making process. Treating of loyalty as a measure of customer attachment to a particular brand, he believes that it reflects the likelihood of customer switching to another brands, especially if these have different price or other parameters [22]. The another concept of the brand loyalty we can meet in works of J. Altkorn. According to this definition, the brand loyalty is not only the propensity of consumers to purchase sustainable products of one brand, but also the willingness to pay a higher price for it, the repetition of the purchases and to refrain from buying competing products [13].

Summing up the above mentioned definitions. The authors may argue that loyalty is a conscious, purposeful and permanent attachment to the brand, manifesting itself in the buyer's substantial engagement with the relations with supplier and the lack of sensitivity to the actions of competitors [8].

However, the brand loyalty may be due to several reasons [13]:

1) conviction of consumer about the value of purchasing the products of the brand (e.g. reliability, modernity),

2) habits (e.g. to certain cosmetics, cigarettes),

3) treatment of the brand as a distinguishing feature of social position.

Due to the benefits from loyalty, the enterprises do a lot of work to - on one hand - encourage customers to become loyal, and on second hand - to retain customers while increasing their value for enterprise. One of the tools that both manufacturers and sellers use is loyalty programs. 


\section{Analysis of recent research and publications}

A research shows that in many cases no more than $10 \%$ of all customers are completely loyal to their suppliers, even when they have excellent reputation. But a value of these most faithful is enormous. In addition, these customers stay longer with the same supplier, buy more often and tend to buy a wider assortment of goods, they also spend more than others.

A research of satisfaction and loyalty of customers of discount stores, supermarkets and hypermarkets conducted by GfK Polonia in 2010 (the survey covered eight leading chains in Poland) prove that average loyal customer is shopping 45 times and disloyal only 3 times. In addition, a value of loyalty customer basket is $222 \%$ of the average, while the value of non-loyal customer basket is only $78 \%$. It means that a loyal customer buy in preferred store one third of all their groceries and FMCG, while nonloyal customer only $1.5 \%$ [2].

However, the turnover generated by loyal customers is amazing. In six stores of one chain, 180 thousand non-loyal customers made purchases worth 12.2 million zlotys per year, and 224 thousand loyal customers generated 310.8 million zlotys turnover. In other situation, 390 thousand non-loyal customers purchased for 20.5 million zlotys, and nearly four times lower number of loyal customers - 98 thousand, made purchases on seven times higher of value and generated sales of 151.7 million zlotys during the year [2]. How to obtain customer loyalty? This is difficult question for many marketing practitioners and theorists. There are several variables that influence on the level of loyalty, among others: quality of products, customer service level, quality of marketing communication, etc. One of the tools for shaping consumer loyalty are loyalty programs. A research of the effectiveness of loyalty programs was conducted, among others by D. Soman (1998) [20], R. Kivetz and I. Simonson (2002) [10] - these authors were checking of impact of delayed incentives on purchase decisions of buyers, or J. Zhang, A. Krishna and S. Dhar (1999) [25], B. Kim, M. Shi and K. Srinivasan (2001) [9], or Kopalle and Neslin (2003) [12], who proposed analytical models to study the importance of loyalty programs. The effectiveness of loyalty programs is also of interest to numerous agencies and business entities that carry out regular research in this area, but in this case they are conducted it in the area of economies of individual countries.

Loyalty programs are defined as long-term marketing activities aimed at building and sustaining positive relationships with selected, most attractive customers. Entrepreneurs implementing these programs are brand owners, ie producers of products and services, but also intermediaries, including retailers. The effectiveness of loyalty programs is often based on a several propositions, such as the following [24]:

1. Customer may want more involving relationships with products that they purchase.

2. A proportion of these customers show tendency to be a loyal.

3. They are profitable group (i.e., 20/80 law).

4. It is possible to reinforce these customers' loyalty through the loyalty program

A loyalty program can accelerate the loyalty life cycle, encouraging a new customers to behave like company's most profitable 10-th-year customer. These customers can became advocacy of brand: they buying more, paying premium prices, and bringing in new customer by referrals [18]. True loyalty arises when exist a real, positive relationship between the supplier and the customer. If they have direct contact, arises a possibility to build a strong customer loyalty through relationships that may be developed between these two entities. It is reasoned in this point to assume that a loyalty program is more than a sales promotion element.

For example, M. Rydel defines a loyalty program as a system of customer loyalty's creation and keeping that is built into the company's market strategy, which aims is to provide close relationships with clients that the company recognizes as solid and offer them more benefits than for a new customers [11].

One of the reason of development of loyalty programs has also, among others, a growth of an information technology. It allowed popularize of loyalty programs in the time of individual marketing. Using them, the customer very often does not even have to leave the house.

One of the branches of the economy where loyalty programs are of particular importance is retail. Many retailers recognize loyalty programs as essential marketing activities. For example, the French network E. Leclerc annually devotes approximately $€ 18$ million from current marketing expenditure on managing his loyalty program [15]. 


\section{The formulation of objectives}

The aim of this study is to define the concept of loyalty program and to analyze the effectiveness of this form of promotion in the Polish economy. The paper assumes that a loyalty program providing real value to the consumer is an effective tool for building customer loyalty.

The article attempts to describe, among others:

- current interest in loyalty programs in Poland;

- perception of loyalty programs by consumers;

- the declared reasons why consumers would increase their interest in loyalty programs;

- most popular loyalty programs in Poland.

In the article a secondary data was used.

\section{Presentation of main materials}

We can observe a decrease in the number of people who declare participation in a loyalty programs was in Poland. In these programs currently participate no more than $40 \%$ of Poles, which means a decrease in the percentage of participants compared to previous years (Figure 1) [17]. According to other sources, this group contain no more than $24 \%$. The rest of the respondents deny to belong to any loyalty program or have a brand loyalty card [4].

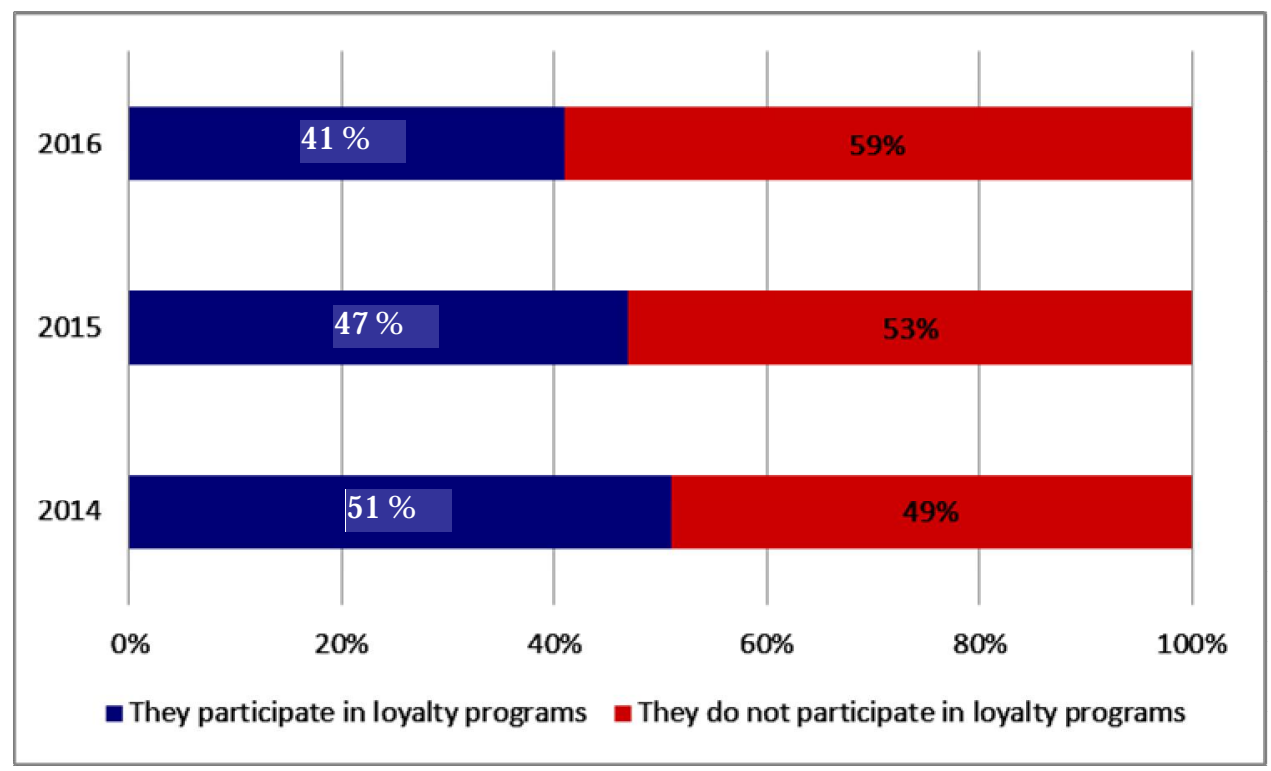

Source: [17].

Figure 1. A participation in loyalty programs

The consumers often see the lack of profitability of collecting points and the apparent benefits of belonging to particular programs. As many as a half of the loyalty program participants declared in 2015, thought the value of the points they received was low and nearly $40 \%$ - that the reward points were very expensive and their price was too high (Fig. 2) [23].

Discounts are indeed small, usually not even exceed $10 \%$ [4]. Meanwhile, Poles expect them to be at a much higher level. For $17 \%$ of a respondents the reason why they can participate in the brand loyalty program is over $50 \%$ rebate. Relatively significant groups would also accept reductions of between 30 and $50 \%-10 \%$ of respondents, $20 \%$ and $29 \%-14 \%$ or $10 \%$ and $19 \%$ - also $14 \%$ of the respondents (Fig. 3) [1].

The respondents relatively low rate the state of their current involvement in the loyalty programs. Only $37 \%$ described their activity as high. The vast majority - almost half, assess their commitment as normal. Some respondents described their status as «withdrawn», indicating their passive attitude to the programs they were offered (Fig. 4) [17]. 


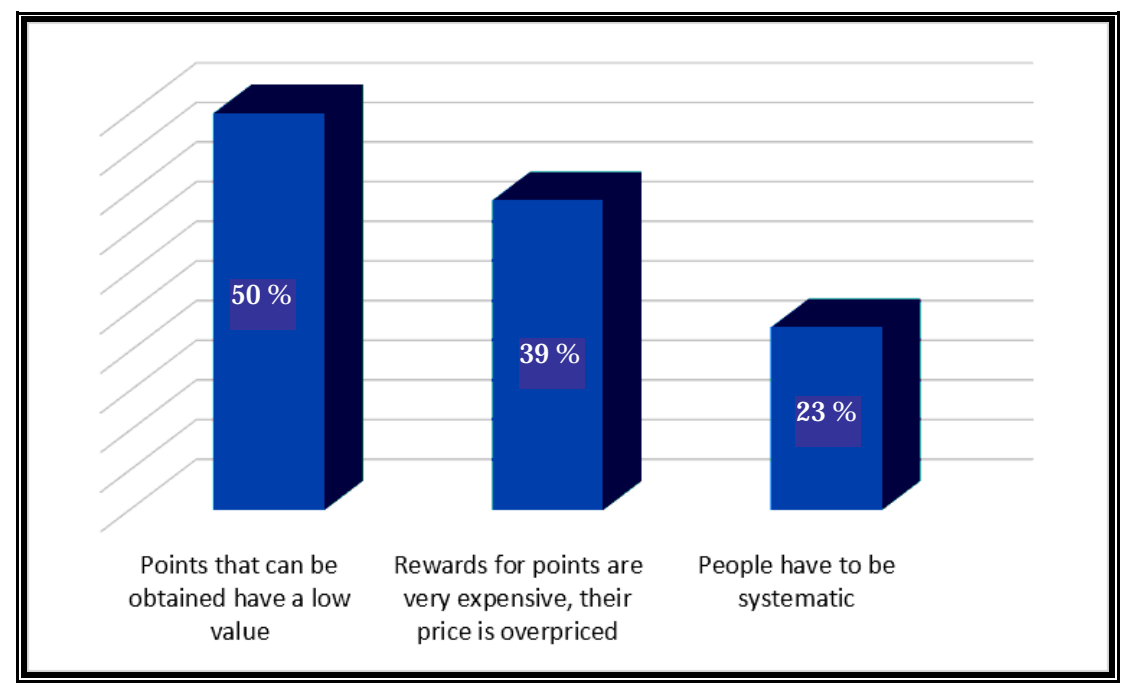

Fig. 2. Main disadvantages of the loyalty programs in Poland (2015)

Source: [23].

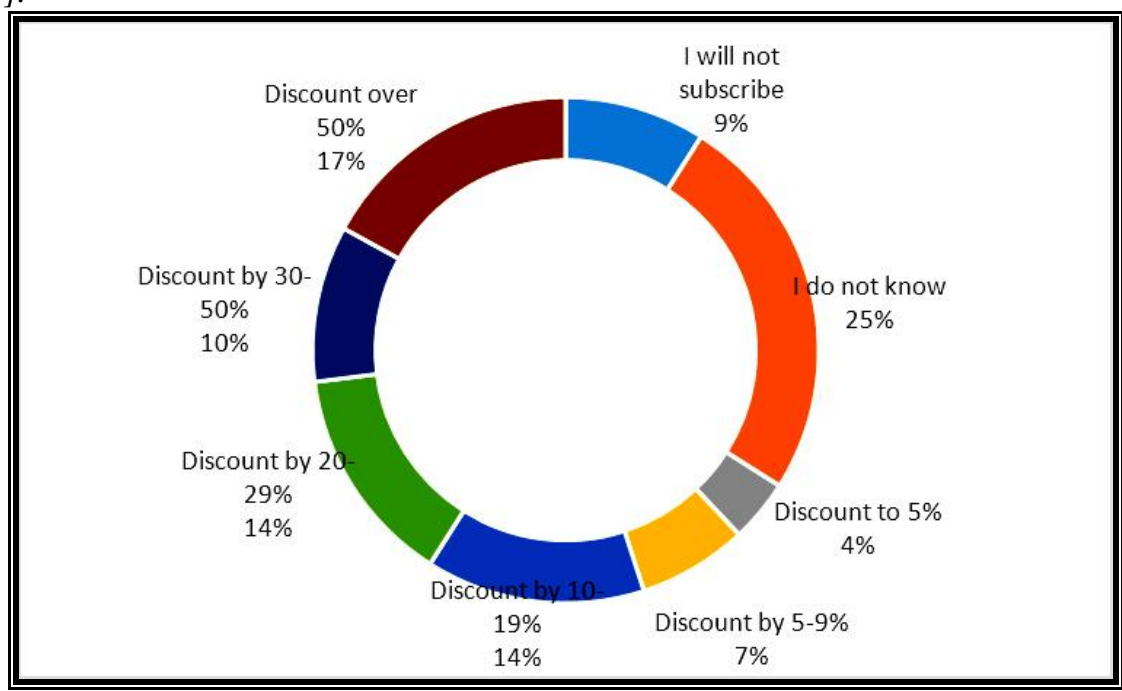

Fig. 3. Attractiveness of the price promotion for which the respondents would subscribe the brand loyalty program

Source: [1].

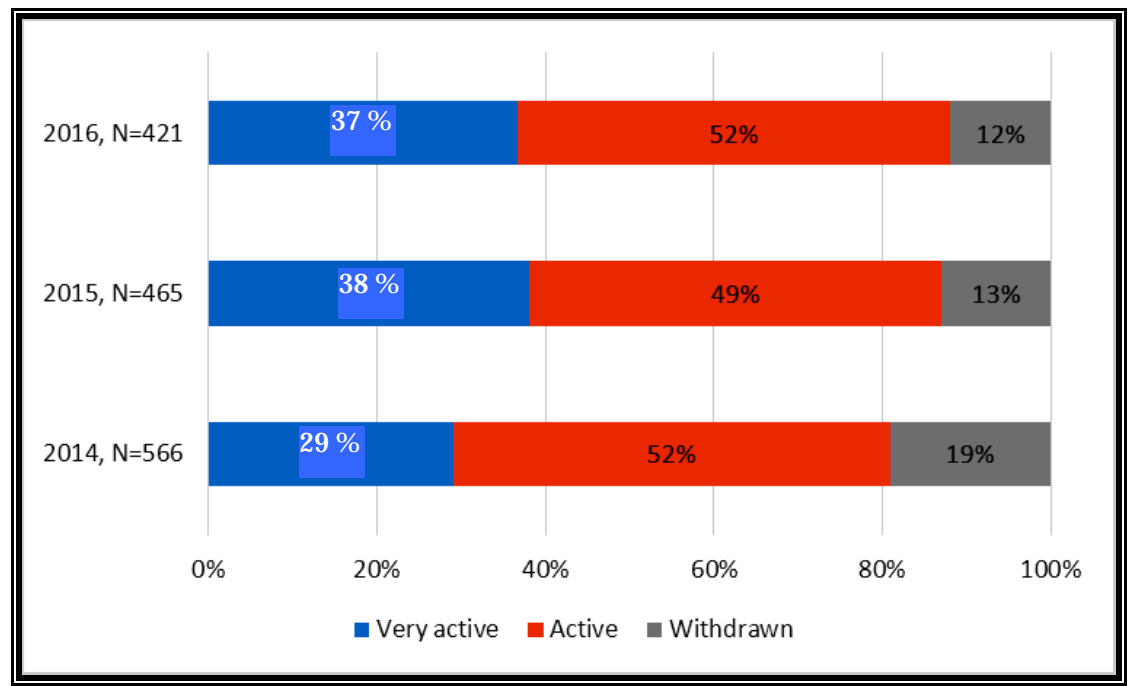

Fig. 4. The activity of participants of loyalty programs

Source: [17]. 
The analysis of declared influence of loyalty programs on respondents' decision making proves that a large group of consumers does not perceive any influence of these programs on their purchasing behavior $-43 \%$. The rest of the respondents observed effects like this. More than one third of respondents (35\%) declare more frequent purchases of products or services offered by the loyalty program. For $16 \%$ of the respondents participation in the loyalty program is a reason to start shopping in the network or with a partner and for similar group $(15 \%)$ is the reason for purchasing products or services from companies that are involved in the same program. This group therefore has the highest activity, and its participation in the loyalty program has prompted her to make major purchases (Fig. 5) [17].

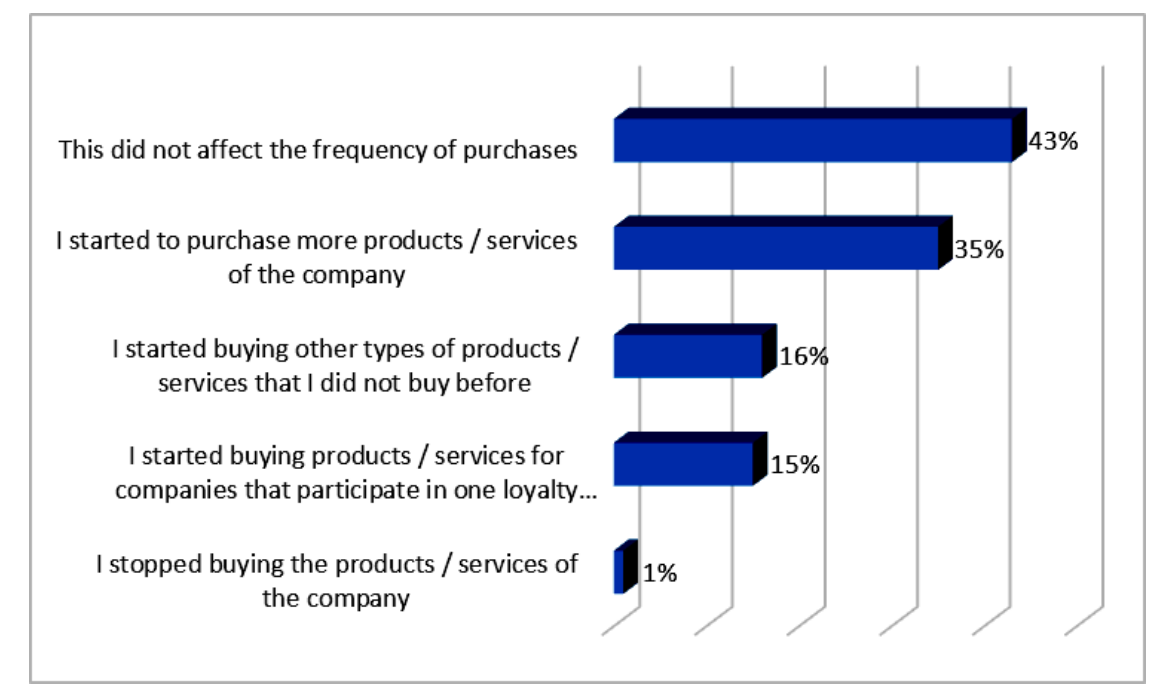

Fig. 5. The influence of participation in the loyalty programs on the purchasing decision of consumer $(2016, N=421)$

Source: [17].

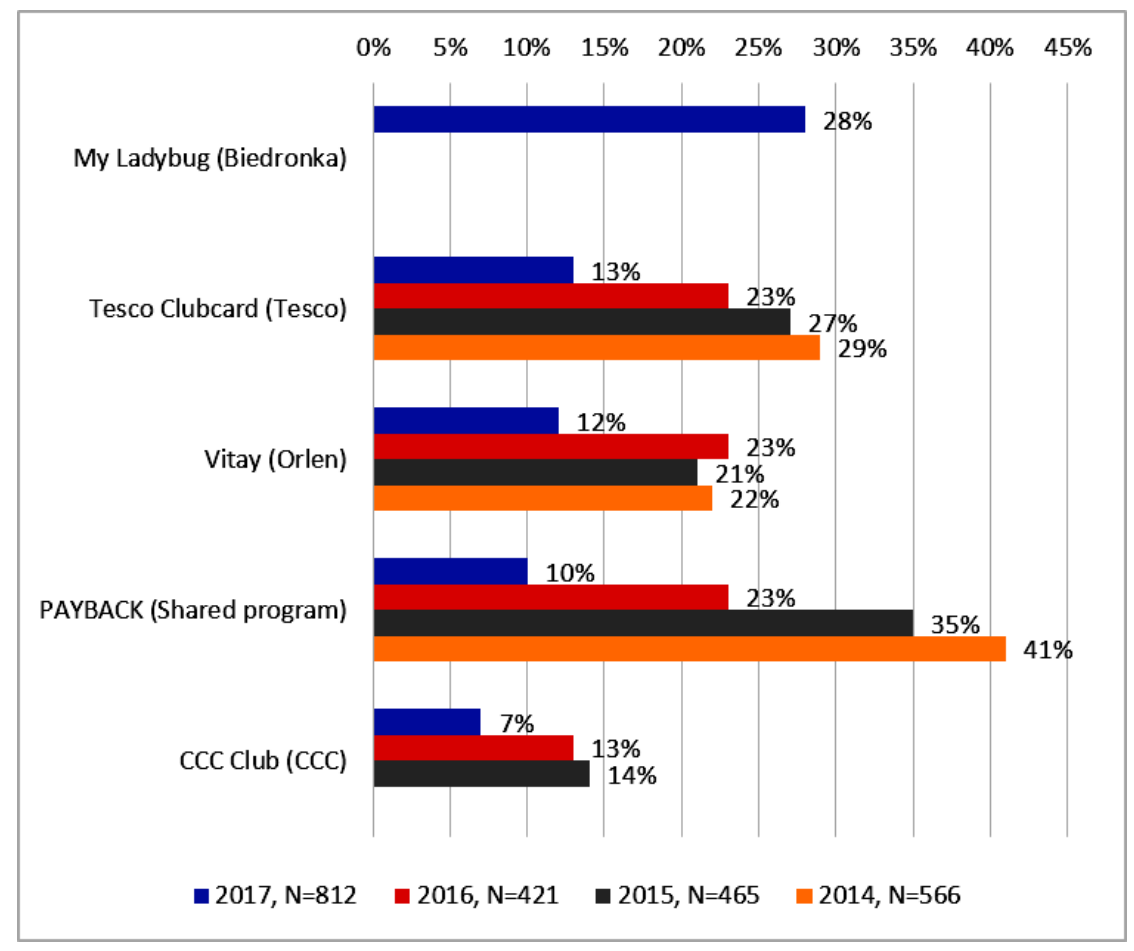

Fig. 6. The most popular loyalty programs (TOP 5) in 2017 in Poland and quantity of the consumers who declared of active participation in these program

Source: $[16,17]$. 
The most popular loyalty programs according to Monitor Loyalty Programs ARC Market and Opinion in 2016 in Poland were: Tesco Clubcard, Orlen - Vitay and Payback. Unfortunately, two of them record systematically declines compared to previous years. The biggest drop in relation to 2015 was recorded by the Payback program - 12 percentage points. The only program that recorded a slight increase in 2016 was Orlen - Vitay [17]. However, the situation on the market of loyalty programs is very dynamic. In 2017 the Poles' greatest interest was gained by the «My Ladybug» program of the Biedronka discount chain (in English: Ladybug) (Fig. 6).

The success of the loyalty program «My Ladybug» was spectacular. In less than six months, customers have registered 5 million cards. Assuming that there are about 13 million households in Poland, it can be estimated that almost $40 \%$ of families use the Biedronka's program [3]. One of benefits for the customers who have registered a card are discounts to $60 \%$ off. The other loyalty programs do not offer such a large discount. The offered rebate therefore distanced itself from the commonly accepted practice and deepened the reductions to a very attractive level. More importantly, the number of products covered by the promotion is relatively large. The consumers therefore can easily take advantage of the promotion , and recognize the economic value of loyalty.

The other Biedronka's actions such as «Gang of Freshmen» were also popular either. In this action, depending on the number of points earned, people could pick up a free or discounted $60 \%$ fruit or vegetable mascots. The promotion was so popular that it finally ran out of plush toys.

According to data from June 2017, the Biedronka chain is a very popular shopping destination in Poland. As many as $62 \%$ of Poles declare that most often do their shopping in Biedronka stores. In the second place was the Lidl network with $9 \%$ of indications, and the third - Tesco with $8 \%$. For $52 \%$ of respondents, Biedronka is a shop that has the best prices. Biedronka also got the highest rating in terms of the best rating $-38 \%$ of respondents indicated this chain [14].

\section{Conclusions and recommendations for further research}

In the time of an active price warfare of many brands, loyalty is one of the assets of the enterprises that is able to protect them against attacks by their competitors. The companies are aware of what is the difference between the value of customers who buy habitually and value conscious customers involved in the relationship with the supplier. The value of purchases made by the so-called loyal customers often exceed the revenues generated by the other groups, and the increase in customer loyalty has a significant impact on the financial performance. Unfortunately, keeping customers and building relationships with them is not easy. The enterprises involved a substantial resources to gain customer loyalty and one of the tools used by them are loyalty programs.

The loyalty programs provide building of consumer loyalty through reward system based on customer history. Their aim is to establish a higher level of customer retention in the profitable segments through higher customer satisfaction and value for the selected customers. The current practice of entities operating in Poland, however, is not attractive to Poles. The persons who participate in loyalty programs regularly withdraw, and those who declare of participation in loyalty programs are very often not involved and their membership in the program has a little effect on their purchasing behavior.

The clients in Poland expect more attractiveness of offered prizes. For many people, the current reward system is cosmetic and is not based on the actual delivery of value to the consumer. Confirmation of the exhaustion of the existing formula of loyalty programs is also a big success of the Biedronka chain, which in half a year managed to persuade more than 5 million people to actively participate in the program. This retail chain, unlike the others, offers significantly higher price reductions for loyal customers. It also encourages increased purchases through additional promotional campaigns, linked to the «My Ladybug» program.

The conclusions should be an indication for subsequent entities planning to implement loyalty programs in Poland. However, the situation in this area is very dynamic, so it will be appropriate to analyze the latest results of consumer preferences research on loyalty programs and the benefits they expect

1. AdRetail, «Smart Okazje - zwyczaje zakupowe Polaków 2017», badanie przeprowadzone metoda CAWI (N=2805). Za: Kilkuprocentowa obniżka już nie wystarczy, żeby zachęcić do zakupów. Klienci oczekujq od sieci większych rabatów, http://adretail.pl/18679-kilkuprocentowa-obnizka-juz-nie- 
wystarczy-zeby-zachecic-do-zakupow-klienci-oczekuja-od-sieci-wiekszych-rabatow (dostęp: 15.09.2017). 2. Analiza GfK Polonia, Najlepszy jest klient lojalny, «Wiadomości handlowe», 3.03.2010, wiadomoscihandlowe. pl (dostęp: 20. 04. 2010). 3. Balawender G., Miliony aktywnych kart Moja Biedronka, Rzeczpospolita, Handel, 9.03.2017. 4. Brak lojalności klientów wynika z niemal permanentnej wojny cenowej, Wiadomości Handlowe, https://www.wiadomoscihandlowe.pl/artykuly/brak-lojalnosciklientow-wynika-z-niemal-permanent,40523/1 (dostęp: 15.09.2017). Badanie przeprowadzone metoda CAWI (N=2805); maj 2017. 5. Capizzi M. T., Ferguson R., Loyalty trends for the twenty-first century, Journal of Consumer Marketing, 22/2, 2005, 72-80. 6. Foxal G. R., Goldsmith R. E., Psychologia konsumenta dla menedżera marketingu, Wydawnictwo Naukowe PWN, Warszawa 1998, s. 31. 7. Howaniec H., Waszkielewicz W., Czynniki ksztattowania lojalności wobec marki, W: Współczesne problemy zarzqdzania przedsiębiorstwami w gospodarce rynkowej, red. nauk. H. Howaniec, W. Waszkielewicz, Wydawnictwo Naukowe ATH, Bielsko-Biała 2008, s. 39-47. 8. Howaniec H., Znaczenie i uwarunkowania lojalności klientów, [w:] Howaniec H., Waszkielewicz W. (red.), Marketingowe i logistyczne determinanty rozwoju organizacji, Wydawnictwo Naukowe ATH, Bielsko-Biała 2010, s. 97-114. 9. Kim B., Shi M., Srinivasan K., Reward Programs and Tacit Collusion, Marketing Science, 20(2), 2001, 99-120. 10. Kivetz R., Simonson I., Earning the Right to Indulge: Effort as a Determinant of Customer Preferences Toward Frequency Program Rewards, Journal of Marketing Research, 39 (May), 2002, 155-70. 11. Komunikacja marketingowa. M. Rydel. (red.), Ośrodek Doradztwa i Doskonalenia Kadr, Gdańsk 2001, s. 71. 12. Kopalle P.K., Neslin S.A., The Economic Viability of Frequency Reward Programs in a Strategic Competitive Environment, Review of Marketing Science, 1, 200, 1-41. 13. Leksykon marketingu, praca zbior. pod red. J. Altkorna, T. Kramera, PWE, Warszawa 1998, s. 135. Maison\&Partners, badanie przeprowadzone na panelu Ariadna, metoda CAVI, w dniach 9-12 czerwca 2017 r. N=1055, https://www.money.pl/gielda/wiadomosci/artykul/maisonpartners-62-polakow-najczesciej-robi,247,0,

2336247.html (dostęp: 15.09.2017). 15. Meyer-Waarden L., The effects of loyalty programs on customer lifetime duration and share of wallet, Journal of Retailing 83/2, 2007, 223-236. 16. Monitor Programów Lojalnościowych, ARC Rynek i Opinia, czerwiec 2017. Za: Programy lojalnościowe zyskuja w matych miastach $i$ na wsiach, http://www.arc.com.pl/programy_lojalnosciowe_zyskuja_w_malych_ miastach_i_na_wsiach-40999642-pl.html (dostęp: 20.09.2017). 17. Monitor Programów Lojalnościowych, ARC Rynek $i$ Opinia, sierpień 2016. Badanie przeprowadzone metoda CATI $(N=1021)$ oraz CAWI (N=802). Za: Spada zainteresowanie programami lojalnościowymi, ARC Rynek $i$ Opinia, http://www.arc.com.pl/spada_zainteresowanie_programami_lojalnosciowymi-41999603-pl.html (dostęp: 15.09.2017). 18. O'Brien L. and Jones Ch., Do Rewards Really Create Loyalty?, Harvard Business Review, 73 (May/June), 1995, 75-82. 19. O'Shaughnessy, Dlaczego ludzie kupuja, PWE, Warszawa 1994, s. 79. 20. Soman D., The Illusion of Delayed Incentives: Evaluating Future Effort-Money Transactions, Journal of Marketing Research, 35 (November), 1998, 427-37. 21. Spada zainteresowanie programami lojalnościowymi, ARC Rynek $i \quad$ Opinia, http://www.arc.com.pl/spada_zainteresowanie_ programami_lojalnosciowymi-41999603-pl.html (dostep: 15.09.2017). 22. Urbanek G., Zarzadzanie marka, PWE, Warszawa 2002, s. 40. 23. Wygnański T., Prawie połowa Polaków korzysta z programów lojalnościowych. Ten wskaźnik niemal nie zmienia się od kilku lat. Polacy za to częściej korzystaja z więcej niż jednego programu - wynika z badania firmy ARC Rynek i Opinia, W: Poradnik. Programy lojalnościowe, $\quad$ s. $\quad 98, \quad$ http://pic.media.com.pl/pic/SKLEP/Do_pobrania/2015/Raport/Sodexo_ Poradnik_MMP_nr_11_2015.pdf (dostęp: 15.09.2017). 24. Youjae Y., Hoseong J., Effects of Loyalty Programs on Value Perception, Program Loyalty, and Brand Loyalty, Journal of the Academy of Marketing Science 31, 2003, 229-240. 25. Zhang J.Z., Krishna A., Dhar S. K., The Optimal Choice of Promotional Vehicles, Management Science, 46 (3), 2000, 348-62. 